DOI: $10.7242 / 2658-705 X / 2019.4 .6$

УДК 551.583

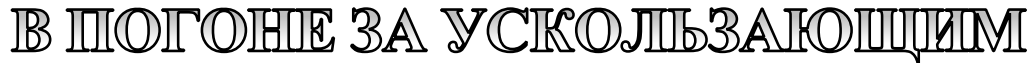

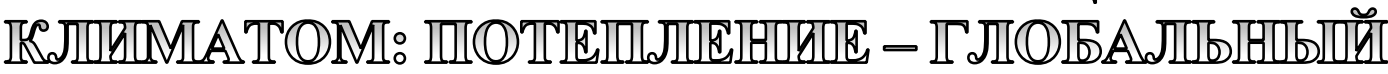 BIGI3OIB XQXUI BBIEIRA *
}

А.П. Соломенный, Институт экологии и генетики микроорганизмов УрО РАН

Для агробиологической науки работы в области изучения устойчивости к температурным колебаниям всегда перспективны, так как подобная динамика во многом определяет распространение и сроки вегетации растений. Современные методы существенно расширили возможности изучения адаптивных систем: молекулярно-генетические реакции позволяют установить порядок и степень экспрессии генов растительного организма, а иммунохимические - присутствие определенных белков в интересующей ткани в определенный момент времени. Число известных участников ответа на температурные шоки неуклонно увеличивается.

Ключевые слова: глобальное изменение климата, растения, акклиматизация, геномика, протеомика.

Глобальное потепление (рис. 1) в ближайшей перспективе уже на 2 градуса предмет широкой научной дискуссии $[3,9,6]$. Работы по адаптации растительного мира к новым условиям получили поддержку на государственном уровне, и большинство актуальных научно-технических задач поставлено в сфере производства продуктов питания. Естественно, в поле зрения находятся вопросы сохранения в изменяющемся мире биологического разнообразия культурных растений.

\section{Метаболизм акклиматизации растений}

Фундаментальные работы привели к серьезным научным прорывам. Белки устойчивости к стрессу, включая тепловой и холодовой шок, выявлены у растений в наиболее уязвимой неблагоприятным воздействиям апикальной меристеме
[15]. По аналогии - это группа плюрипотентных стволовых клеток. Понятно, что изучать процессы дифференцировки подобного материала весьма непросто. Так,

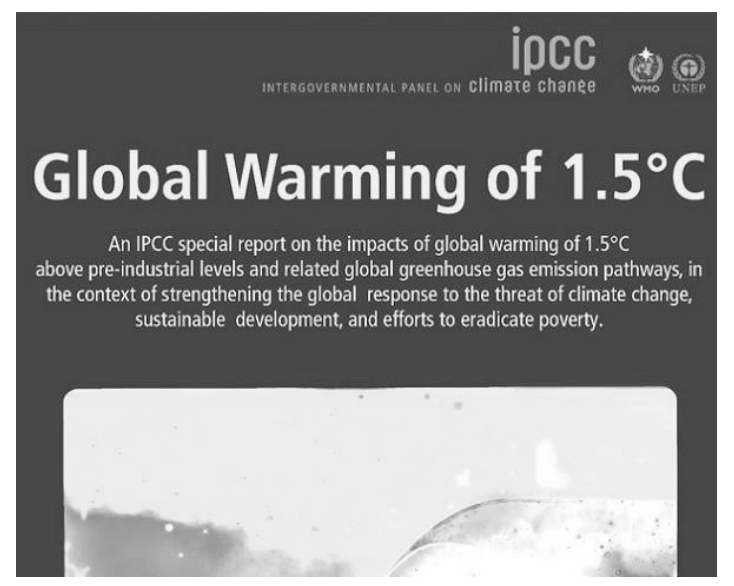

Рис. 1. Титульный лист специильного доклада о глобальном потеплении от 6 октября 2018 г., утвержденного на 48-й сессии межправительственной группь экспертов по изменению климата МГЭИК (с разрешения)

* Работа выполнена в рамках государственного задания, номер государственной регистрации темы: № 01201353247. 
растительные белки позднего эмбриогенеза, или Lea proteins стали известны всего 25 лет назад [11]. Совсем недавно прояснено отсутствие у них специфичности. Оказалось, что сопротивляемость охлаждению листьев клубники можно усилить экспрессией одного из генов тканевого lеа-дегидрина пшеницы.

Разнообразие белков холодового шока (БХШ) изучено гораздо более полно, они представлены в клетках микроорганизмов, животных и высших растений. Низкомолекулярные шапероны, или $Y$ box proteins, стабилизирующие различные РНК, например у хлоропластов в ответ на переохлаждение, исторически наиболее подробно исследовались у пшеницы как основной зерновой культуры холодного пояса [14]. Установлено, что при общей схожести разные белковые фракции накапливаются при акклиматизации различных сортов, причем модель накопления имеет тканеспецифичность - от меристемы до семян на стадии молочной зрелости.

По результатам многолетних экспериментов эволюционно сложившиеся микробно-растительные ассоциации представляются специалистам «волшебной палочкой» повышения стрессоустойчивости и, главное, урожайности [4].

Лишь недавно внимание привлекла способность микроорганизмов к продукции льдонуклеирующих агентов, влияющих на микроструктуру и физико-химические свойства льда. Такие протеиноподобные агенты впервые были обнаружены у бактерии Pseudomonas syringae, выделенной на листьях сирени. Удивительно, но на практическом опыте мы давно знаем, что сирень зацветает именно к холодам. Проявление нуклеирующей активности выражается в контролируемом замерзании внеклеточной воды выше известной точки на 1,5-2 градуса. При этом мельчайшие зерна льда все же могут разрывать тканевую структуру растения, приводя к некрозу [13].

Псевдомонады находили в уникальных микробно-растительных сообщест- вах. Один из таких штаммов выделен в нашей лаборатории (номер ГенБанк MK968370) из лишайникового сообщества оазиса Бангера, что располагается в восточной части Антарктиды. Причем, оазис в антарктическом понимании экстремально сухая долина (полярники сравнивают с марсианскими, хотя, конечно же, условно - среднегодовая температура воздуха здесь всего минус $9^{\circ} \mathrm{C}$ ), лишенная постоянного ледового покрова, а данный оазис еще и удален от побережья на несколько десятков километров [5]. Наш штамм способен расти при 3-4 ${ }^{\circ} \mathrm{C}$, т.е. температуре индуцированой нуклеации льда (см. выше).

Впрочем, даже в Антарктиде произрастают злаковые, например, щучка (луговик) антарктическая Deschampsia antarctica. Субантарктические острова, безусловно, важны в экологическом мониторинге, здесь на архипелагах Кергелен, Крозе, Принс-Эдуард и Южных Шетландских островах регулярно работают ученые, в т.ч. и российские на станции Беллинсгаузен. Источники сообщают, что потепление привело к расширению ареала упомянутого злака в двадцать пять раз.

Что же говорить о неморальных видах и их микробных ассоциантах. Щучку дернистую можно встретить на широких просторах Европейской территории страны и в Сибири. В нашем климате и почвах представители рода Pseudomonas нередко доминируют среди неспоровых микроорганизмов ризосферы пшеницы в фазе колошения [2]. Для растений же микробиом ризосферы, как установлено, столь же важен для здоровья, что для человека микробиом пищеварительной системы [9]. Относительно перспектив практического использования бакпрепаратов на основе Pseudomonas в защите растений от заморозков можно судить по опубликованным результатам, например, для Ps.fluorescens [1].

И про капусту... Кергеленская капуста по внешнему виду напоминает обычную и относится к тому же семейству. Видовое название связано с тем, что впервые она открыта именно на о. Керге- 
лен, заморской территории Франции. Но не всякая французская капуста попадает на почтовую марку (рис. 2).

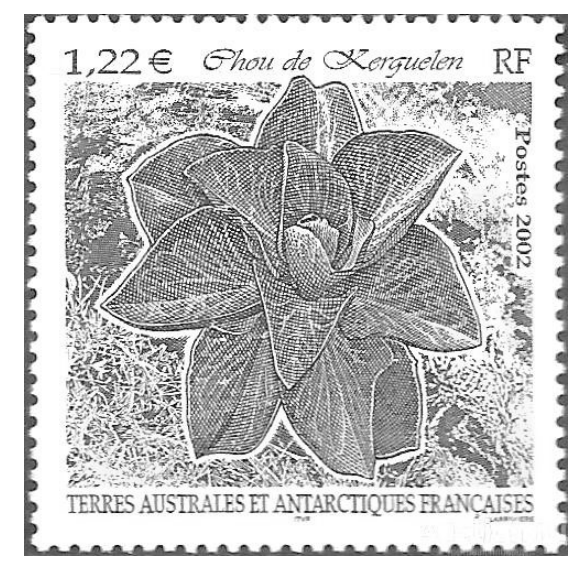

Рис. 2. Кергеленская капуста - одно из растений, наиболее устойчивых к переохлаждению

Кергеленская капуста спокойно переносит мягкие заморозки в период цветения. В генетическом отношении такие организмы - ценнейший объект исследования транскрипционных факторов, что управляют экспрессией генов. Их интенсивно изучают биотехнологи, приспосабливая к своим конкретным задачам.

\section{Заключение: что происходит сегодня в мировых лабораториях и какими станут биоагротехнологии будущего}

Вне сомнения, биотехнологии приобретают свойство climate-smart. В сравнении с химическим синтезом умные синтетические биотехнологии способны минимизировать совокупный объем эмиссии парниковых газов. Что же касается введения в оборот новых агротехнологий - на первый план здесь, безусловно, выходят вопросы биологической безопасности. В этом аспекте своевременно и современно звучит призыв всячески оберегать проверенные староместные локальные сорта и биоресурсные центры (коллекции), обеспечивающие хранение семян $[6,7]$. Все же остается загадкой, как будут функционировать психротолерантные фито-ассоцианты при умеренных температурах. Возможно, они перестроят систему синтеза биологических антифризов и более активно приступят к продукции иных стрессовых соединений.

Молекулярно-генетические особенности реакций растений озимой пшеницы на высокотемпературные воздействия сейчас интенсивно изучаются. Показано, что в геноме пшеницы Triticum aestivum L., который составляет 107000 генов, при воздействии температуры $40^{\circ} \mathrm{C}$ в течение 1 ч усиливается экспрессия более 5000 генов, а экспрессия более 6000, напротив, снижается [6].

Выражаю благодарность к.б.н. Шаравину Д.Ю. (лаборатория водной микробиологии ИЭГМ УрО РАН) за блестящее экспериментальное сопровождение работы.

\section{Библиографический список}

1. Воробейков Г.А., Бредихин В.Н. Микроорганизмы в агробиотехнологиях и защите природной среды: учеб. пособие. - СПб.: Изд-во РГПУ им. А.И. Герцена. 2018. - 219 с.

2. Гордеева Т.Х., Масленникова С.Н., Гажеева Т.П. Формирование микробнорастительных сообществ ризосферы в онтогенезе зерновых культур // Науч. журн. Кубанского гос. аграрного ун-та. - 2012. - № 81(07).

3. Дружинин П.В. Влияние климатических изменений на урожайность в сельском хозяйстве Карелии // Уч. зап. Российского гос. гидрометеорологического ун-та. - 2015. - № 38. - С. 201-208.

4. Ковалевская Н.П., Шаравин Д.Ю. Бессонова Л.В. Роль микробно-растительных симбиозов в повышении стрессоустойчивости зерновых культур в условиях Предуралья // Вестник Пермского научного центра. - 2018. - № 1. - С. 30-36.

5. Крыленков В.А., Гончаров А.Е. Микробиота земной криосферы. - СПб.: - Фолиант. - 2019. - 444 с.

6. Ляпунова O.A. Средиземноморские староместные сорта твердой пшеницы, сохраняемые в коллекции ВИР // Труды по прикладной ботанике, генетике и селекции. - 2018. - 179(3) - С. 68-84.

7. Нилова И.А. Устойчивость растений пшеницы к высокотемпературным воздействиям разной интенсивности: физиолого-биохимические и молекулярно-генетические аспекты / Дис... канд. биол. наук: - Петрозаводск, Институт биологии Карельского научного центра РАН, 2019. - 164 с.

8. Хусенов Б., Отамбекова М., Моргунов А., Муминджанов Х. Староместные сорта пшеницы на фермерских полях в Таджикистане: обзор, сбор и сохранение на национальном уровне, 2013-2015 гг. // Продовольственная и сельскохозяйственная организация объединенных наций. - ФАО, Анкара, Турция, - 2016. - 33 с. 
9. Aydinalp C., Cresser M.S. The effects of global climate change on agriculture // American-Eurasian J. Agricult. Environ. Sci. - 2008. - Vol. 3. - P. 672-676.

10. Berendsen, R.L., Pieterse, C.M., Bakker, P.A. The rhizosphere microbiome and plant health // Trends Plant Sci. - 2012. - Vol. 17. - P.478-486.

11. Hundertmark M., Hincha D.K. LEA (late embryogenesis abundant) proteins and their encoding genes in Arabidopsis thaliana // BMC Genetics -2008. - 9:118.

12. Hutchins D.A., Jansson J.K., Remais J.V. [et al.] Climate change microbiology problems and perspectives // Nat. Rev. Microbiol. - 2019. - Vol. 17 (6). - P. 391-396.

13. Qianqian Li, Qi Yan, Jinsi Chen, [et al.] Molecular characterization of an ice nucleation protein variant (InaQ) from Pseudomonas syringae and the analysis of its transmembrane transport activity in Escherichia coli // Int J. Biol. Sci. - 2012. -Vol. 8. - P. 1097-1108.

14. Radkova M., Vitámvás P., Sasaki K., Imai R. Development and cold-regulated accumulation of cold shock domain proteins in wheat // Plant Physiol. Biochem. - 2014. - Vol. 77. - P. 44-48.

15. Sachs M.M., Ho T.-H.D. Alteration of gene expression during environmental stress in plants // Ann. Rev. Plant Physiol. - 1986. - Vol. 37. - P. 363-392.

16. Sterner T. [et al.]. Policy design for the Anthropocene. // Nat. Sustain. - 2019. - Vol. 2. - P. 14-21.

\title{
CHASING AN ELUSIVE CLIMATE: GLOBAL WARMING CHALLENGE
}

\author{
A.P. Solomennyi \\ Institute of Ecology and Genetics of Microorganisms UB RAS
}

Studies in the field of temperature fluctuations resistance are promising for agrobiology since these changes largely determine distribution and timing of plant vegetation. Contemporary methods have significantly expanded the possibilities in research of adaptive systems: molecular reactions and immunochemical methods lead to specify the order and degree of genes expression and presence of certain proteins in tissues at a particular stage, hence steadily increasing the number of participants in the response to temperature shocks.

Keywords: global climate changes, flora, acclimatization, genomics, proteomics.

\section{Сведения об авторе}

Соломенный Александр Петрович, кандидат биологических наук, старший научный сотрудник лаборатории водной микробиологии, Институт экологии и генетики микроорганизмов УрО РАН филиал Пермского федерального исследовательского центра УрО РАН (ИЭГМ УрО РАН), 614081, г. Пермь, ул. Голева, 13; e-mail: solomen@iegm.ru 